\title{
Psychological Support for the Foreign Language Training of the Students at International Relations Faculties
}

\author{
Svitlana Lysenko ${ }^{1}$, Nina Lavrynenko ${ }^{1}$, Andrii Bohuslavets ${ }^{1}$, Maryna Kryvych ${ }^{2}$, Leonid Oliynyk ${ }^{3}$, \\ Vasyl Stasyuk $^{4}$, Oleksandr Lahodynskyi ${ }^{5}$, Vasyl Osyodlo ${ }^{6}$, Vasyl Yahupov ${ }^{7}$, \\ Valentyna Hrishko-Dunaievska ${ }^{8}$, Ihor Bloshchynskyi ${ }^{9, *}$, Volodymyr Artemov ${ }^{10}$ \\ ${ }^{1}$ Training-Support Laboratory, Military Diplomatic Academy named after Yevheniy Bereznyak, Ukraine \\ ${ }^{2}$ Foreign Languages Training and Scientific Center of the National Academy of Security Service of Ukraine, Ukraine \\ ${ }^{3}$ Resource Center of Educational Activity, National Defense University of Ukraine named after Ivan Cherniakhovskyi, Ukraine \\ ${ }^{4}$ Department of Moral and Psychological Support of the Activity of the Troops (Forces), National Defense University of Ukraine \\ named after Ivan Cherniakhovskyi, Ukraine \\ ${ }^{5}$ Department of Foreign Languages, Military Diplomatic Academy named after Yevheniy Bereznyak, Ukraine \\ ${ }^{6}$ Institute of Humanities, National Defense University named after Ivan Cherniakhovsky, Ukraine \\ ${ }^{7}$ Department of Social Disciplines, National Defense University named after Ivan Cherniakhovskyi, Ukraine \\ ${ }^{8}$ Department of English Language, Faculty of Foreign Languages and Humanities, Bohdan Khmelnytskyi National Academy of the \\ State Border Guard Service of Ukraine, Ukraine \\ ${ }^{9}$ Department of English Translation, Faculty of Foreign Languages and Humanities, Bohdan Khmelnytskyi National Academy of the \\ State Border Guard Service of Ukraine, Ukraine \\ ${ }^{10}$ Department of Professional Pedagogy and Psychology, National Academy of Security Service of Ukraine, Ukraine
}

Received March 2, 2020; Revised March 27, 2020; Accepted April 19, 2020

Copyright $\mathrm{C} 2020$ by authors, all rights reserved. Authors agree that this article remains permanently open access under the terms of the Creative Commons Attribution License 4.0 International License

\begin{abstract}
The article studies the innovative elements of psychological support for the professional foreign language training of students at international relations faculties, offers and experimentally verifies the effectiveness of techniques and exercises for the intensification of the foreign language training, based on professional communicative situations in high-risk foreign language environment. Such elements include the use of stress-management techniques and exercises based on real-life professional situations, along with practicing foreign language skills. The appropriateness of use of the elements of psychological support for the professional foreign language training of would-be professionals in international relations was proved to be effective through the experiment. It was conducted with students of international relations faculties through the comparison of levels of performance of two groups of students: those whose professional foreign language training include elements of psychological support and those with traditional training. In order to assess the difference between two groups of students at the summative stage of the experiment, the Mann -Whitney U test was used. The use of psychological support for the professional foreign language training is significant in terms of improvement of
\end{abstract}

would-be specialists' in international relations professional competence.

Keywords Psychological Support, Foreign Language Training, International Relations Professionals, Stress-Management Techniques and Exercises

\section{Introduction}

In today's world, most nations are active members of international and intergovernmental organizations. It requires highly qualified specialists in the area of international relations, able to speak foreign languages at the professional level. One of the elements of foreign language training (FLT) at international relations faculties is the systematic and creative use of psychological support for foreign language lessons. It cannot be effective without using methods of personality-oriented approach and integrated training, as well as up-to-date informational and communicational technologies. Today's labor market requires specialists in international relations to be creative, and possess versatile abilities, including high level of IQ, 
emotional intelligence, professional qualities and foreign language abilities, as well as highly developed communication skills that they would be able to use both in standard and high-risk (psychologically tense) environments.

Therefore, students in the area of international relations should develop a high level of professional foreign language competence (FLC) during their FLT.

Finally, the future jobs of such specialists take place in psychologically tense conditions requiring comprehensive moral, psychological, professional and personal readiness, i.e. combining FLC development with a high level of stress management in order to enable students' speedy and effective performance of their professional functions.

Thus, the effective FLT of highly competitive specialists in international relations, acquiring proper level of FLC combined with professional abilities of stress management in the high-risk foreign language environment, is a priority task for international relations faculties. In turn, this highlights the significance of innovative approaches to professional FLT, where establishing interdisciplinary relations envisaging a combination of such elements as stress management, using foreign language learning materials with professional topics and situations in high-risk language environment that would eventually contribute to effective professional FLT.

\subsection{The Aim}

The objective of this research is to study the innovative elements of psychological support for the professional FLT of students at international relations faculties as well as to offer and experimentally verify the effectiveness of techniques and exercises for the intensification of the FLT, based on professional communicative situations in high-risk foreign language environments.

\section{Materials and Methods}

\subsection{Literature Review}

The theory of FLC was under thorough research of A. Leontyev (2007), a leading Russian psychologist and linguist. In his work, the scholar has defined and described such notions as 'language', 'speech' and 'speech activity', putting clear distinctions between them and making them classical for all sciences dealing with languages and their teaching and learning.

The general goals of teaching and learning foreign languages within the competence approach were set forth and scientifically substantiated by S. Nikolayeva (2010), a leading Ukrainian scholar on the methodology of foreign language teaching. They can be applied to any type of educational institutions, although they require some specifications due to the professional conditions of language environment.

The issues of creating foreign language environment in the English class by means of content-based warm-ups at its initial stage have been revealed in the research of $M$. Karpushyna, I. Bloshchynskyi, A. Nakonechna, K. Skyba (2019). They emphasize that a special role in performing this task is given to the lesson starters which can trigger any learning activity, set relevant pace, create psychological atmosphere, develop spontaneous speech, intensify cadets' attention, as well as prepare their organs of perception and speech for listening and speaking English.

The fundamental research on psychology of stress and its influence on professional activity was made by $\mathrm{N}$. Nayenko (1976), E. Nosenko (1981), B. Smirnov \& E. Dolgopolova (2007). They clearly describe a state of emotional stress, its causes and negative influence on human professional activity and speech referring to earlier works of Western psychologists, as well as to their own experimental works. Some practical implications for stress management for high-risk operatives are provided in the later work of Russian psychologists V. Rybnikov \& E. Ashanina (2011).

Among all the high-risk professions, the jobs in the military are the ones mostly covered by research in terms of stress influence on their professional activity. Here, we find a work of V. Stasyuk (2000) making a detailed professional description of high-risk environment in terms of combat actions and its influence on individual peculiarities of military personnel.

Some contributions to scientific substantiation of military high-risk foreign languages environment and the peculiarities of teaching foreign languages to high-risk operatives were made in our earlier works, i.e., O. Lahodynskyi (2018) and O. Lahodynsky \& I. Semenyako (2018). Some details on these issues can be also found in the works of I. Bloshchynskyi (2017) dealing with the enhancement of Ukrainian would-be border guards' practical training, and using some computer programs to intensify the learning process of these military specialists.

However, the problem of peculiarities of using foreign language has not been given enough consideration not only in standard but also in high-risk environments. This is particularly relevant to conditions of increased psychological tension connected with the complications and volume of professional knowledge, lack of time for their performance, different factors of stress. Solution of these problems requires integration of knowledge from different fields of research and practice as well as systematic thinking.

\subsection{Participants}

The research was carried out through the use of an experiment including the three basic stages: fact-finding, progressive and summative. The participants of the experiment were 36 students of international relations faculties of Military Diplomatic academy named after 
Yevheniy Bereznyak and 8 experts from various military academies (Ukraine).

\subsection{Research Procedure}

The research order was established as follows: organization of expert teams; identification of the experiment aim; selection of instruments; questioning of experts and respondents; data-processing and decision-making. At the first stage, a team of experts was established. Their number (Nexp) was identified based on preciseness of experts' evaluation $(\varepsilon)$ and preset reliability $(\beta)$, according to the following formulas:

$$
\mathrm{N}_{\exp }=\mathrm{t}_{1}^{2} \mathrm{~W} / \varepsilon \text {, }
$$

where $t_{1}$ is a tabular coefficient depending on $\mathrm{W}-\mathrm{a}$ coefficient of evaluations variation.

In order to obtain experts' evaluation with the preciseness not lower than $\varepsilon<0,1$ and reliability $\beta 1>0,9$ (t $=2,1$ ), we agreed on eight experts as an optimum number in the team for the experiment. Besides, experts had to meet very tough requirements such as professional competence, objectivity (impartiality), high level of motivation.

The experts established the factual state of FLC of the students at international relations faculties and their ability to use stress- management techniques.

At the second stage, we developed and used elements of psychological support for the professional FLT of the would-be professionals in international relations, combining use of FLC development materials with stress-management techniques.

At the final stage of the experiment, we made up two groups of students in international relations. The first group did not use elements of psychological support for the professional FLT, while the second one - the experimental group - did use foreign language materials combined with stress-management techniques. The results were processed, analyzed and correlated, proving the efficiency of the proposed use of the psychological support. In order to assess FLC in combination with stress-management abilities, we referred to the following criteria (Table 1).

Table 1. Basic criteria of the students' levels of FLC and stress-management ability

\begin{tabular}{|c|c|c|}
\hline Criterion & Criterion components & Descriptors \\
\hline Motivational & $\begin{array}{l}\text { Aims, needs, wants, values and interests stimulating } \\
\text { students' active actions in order to increase efficiency of } \\
\text { their studies and professional activity. } \\
\text { Students' satisfaction with their would-be profession, their } \\
\text { orientation at productive studies and stress-management } \\
\text { abilities, realistic level of expectations. } \\
\text { Readiness for responsible professional actions in high-risk } \\
\text { foreign language environment. }\end{array}$ & $\begin{array}{l}\text { Hierarchy of values. } \\
\text { Motivation at the success, achievement and avoiding } \\
\text { failures. } \\
\text { Understanding necessity to acquire stress-management } \\
\text { skills as well as achievement of supreme level of FLC. } \\
\text { Students' positive attitude towards the idea of self-learning } \\
\text { of stress-management techniques in connection with FLC } \\
\text { acquirement. }\end{array}$ \\
\hline Operational & $\begin{array}{l}\text { Students abilities of self-organization, planning, } \\
\text { self-control, rational use of time and resources. } \\
\text { Identification of own training goals and necessity of } \\
\text { acquiring stress-management techniques. } \\
\text { Abilities to choose foreign language exercises and } \\
\text { stress-management techniques for the professional } \\
\text { activity; abilities of their self-implementation and } \\
\text { development evaluation. }\end{array}$ & $\begin{array}{l}\text { Systematic approach, high level of organization, success, } \\
\text { persistence in pursuing own educational and professional } \\
\text { goals. } \\
\text { Ratio between orientation, execution and supervision } \\
\text { actions during self-use of stress-management techniques } \\
\text { while learning foreign languages. }\end{array}$ \\
\hline Professional & $\begin{array}{l}\text { Students' understanding sense and necessity of educational } \\
\text { and professional activity in combination with high level of } \\
\text { stress-management abilities and supreme level of FLC. }\end{array}$ & $\begin{array}{l}\text { Objectivity of evaluating one's own readiness for active } \\
\text { educational and would-be professional activity. } \\
\text { Having of distinct structure of educational and professional } \\
\text { priorities; desire to improve foreign language use in } \\
\text { high-risk environment. }\end{array}$ \\
\hline Cognitive & $\begin{array}{l}\text { Levels of stress-management abilities at different stages of } \\
\text { FLC development (from reproductive to supreme). } \\
\text { Integration of students' professional skills. } \\
\text { Spectrum of the stress-management abilities and foreign } \\
\text { language skills. }\end{array}$ & $\begin{array}{l}\text { Emotional self-control. } \\
\text { Abilities to use stress-management techniques } \\
\text { corresponding to the supreme level of FLC and general } \\
\text { professional training. } \\
\text { Profoundness of professional foreign language skills and } \\
\text { stress-management abilities. } \\
\text { Understanding practical purpose of comprehensive skills. }\end{array}$ \\
\hline Reflexive & $\begin{array}{l}\text { Students' abilities of self-evaluation, self-control, } \\
\text { reflection achievements analysis during professional } \\
\text { foreign language training. } \\
\text { Abilities to find cause-effect links and draw adequate } \\
\text { conclusions as to the levels of FLC in combination with } \\
\text { stress-management skills. }\end{array}$ & $\begin{array}{l}\text { Students' abilities of critical analysis of setting out one's } \\
\text { own educational and professional goals in professional } \\
\text { FLT; self-control in their use. } \\
\text { Reflection on one's own levels of expectations from } \\
\text { professional FLT. }\end{array}$ \\
\hline Personal & Students' activeness in professional FLT. & $\begin{array}{l}\text { Students' desire to increase their levels of FLC in } \\
\text { combination with stress-management skills. }\end{array}$ \\
\hline
\end{tabular}


We used various theoretical methods throughout the research, such as theoretical analysis and synthesis in order to set out the purpose, hypothesis, object and goals of the research; analysis of special and educational resources; analysis, comparison, classification and generalization of theoretical data; theoretical modeling in order to establish theoretical, methodological and practical aspects of the research, aimed at making up the elements of psychological support for the professional FLT of the would-be professionals in international relations.

The experimental methods included questionnaires, tests, self-assessment techniques in order to establish the attitude of students towards using psychological support in FLT; and experts' conclusions on their virtual state of FLC development, and use of stress-management techniques. We also used experts' assessment, questioning and testing to establish levels of development of these skills and qualities. Progressive and summative stages of the experiment were used to establish correlations between professionally oriented components of psychological support for the professional FLT and the elements of FLT, as well as to verify the efficiency of the organizational conditions of their use. Statistical methodologies were used for ranging and statistical substantiation of the results. Here, the Mann -Whitney U test was used to assess differences between two groups of students at the summative stage of the experiment, correlation and statistical analysis for generalization and interpretation of the research experimental data, establishment of dependencies between psychological and educational processes which were part of research.

The basic instruments for the analysis of the experiment were standard questionnaires for students and experts. Their questions were different in terms of content, form and functions.

In order to effectively analyze the results of questioning, the instructions to the questionnaires for the experts offered to note their expertise and degree of preparedness on the issues of questioning.

At the same time the instructions to the questionnaires for students were aimed at encouraging sincere feedback from the students that could contribute to the improvement of the educational process.

Recommendations which were made by experts and students obtained at the prior questioning as well as requirements to the professionals and job needs were considered. In the process of the research, it was established that the materials reflected both objective and subjective views of the respondents and experts as to FLT. Therefore, it was found reasonable to supplement them with data analysis obtained by means of other methods.

In order to assess the professional competence of the experts involved in experiment, statistical methods were used to determine experts' competence coefficient. In order to assess the difference between the two groups according to certain features, and to identify the difference between small groups of students, the Mann -Whitney U test was used.

Overall, the reliability and validity of the research are supported by various research and theoretical analysis of the problem, congruence of the methods with the research goals, adequate mathematical methods for data processing as well as a wide range of respondents.

We also considered these requirements when using techniques of stress management such as effectiveness, and time limitation. Along with this, the techniques should not have been distractive for students and created negative emotions on them.

At the progressive stage of the experiment, we used both general (e.g., exercises, based on behavioral psychology), innovational (e.g., functional music) and special techniques.

At the summative stage of the research, we divided students into control and experiment groups. The groups were formed based on the students' homogeneous general and professional skills and knowledge, average age, professional attitude, and psycho-physiological qualities. The most important requirement to support the reliability and credibility of the research results was that the FLT in the control group was based on the traditional techniques, while the psychological support for the professional FLT was used in the experimental group. The statistics proved that this technology was more efficient.

Statistics and analysis of the results obtained from the research show almost 93\% respondents considered it necessary to improve their FLC using the elements of psychological support. $25 \%$ of the respondents were sure that this guarantees their successful performance of professional functions. Almost $20 \%$ of the respondents offered development of integrative competences using stress-management techniques at the foreign language lessons, and $26 \%$ thought it was a favorable groundwork for their further efficient psychological training for actions in high-risk environment as an integral part of their professional competence. Also, $42 \%$ of those being questioned considered that they should have been prepared to adapt to any stress conditions on their own as an ability to do so could affect professional foreign language communication in high-risk environment. The majority of the respondents $(73 \%)$ also considered the successful development of a high level of FLC, combined with stress-management techniques, depended on students' level of motivation. Highly motivated students, on average, tend to work more by $41 \%$ and usually achieve high results both in acquiring foreign languages and stress-management skills.

It should also be noted that the psychological basis of foreign language competence is the emotional intelligence including emotional self-awareness, emotional self-control, emotional self-motivation, empathy, and handling relationships. 


\section{Results}

The research results contain the development of practically efficient and scientifically substantiated professionally-oriented range of stress-management techniques, presented in a manual, and supported by audio materials. A differentiating testing methodology of integrative competence assessment has also been developed. It shows dynamics of changes in the cutoff knowledge coefficient (CKC) of the students in both the control and the experimental group prior to the experiment (input testing) and after using elements of psychological support at the foreign language lessons (output testing). Figure 1 illustrates the $\mathrm{CKC}$ with the tangent of the inclination angle (Urbach Rule).

Figure 1 demonstrates that the bachelors and specialists (a degree in Ukraine between bachelor and master) have slightly lower exponents of CRC (almost 35\%). After an integrative use of the stress-management techniques, we can observe a decrease by almost $21 \%$. Overall, this increases students' level of FLC by $14.3 \%$ in the experimental group and by $8.1 \%$ in the control group.

As a result of the research, the integrated influence of the use of stress-management techniques at the foreign language lessons and students' motivation at their exercises undertaken has also been established. We also identified levels of exercises the students had to do at the foreign language lessons prior to and after the experiment, depending on their motivation.

The results analysis shows that during preliminary training (input testing) the students performed such tasks (exercises): $56 \%$ of the algorithmic level, almost $35 \%$ of the prognostic level and above $90 \%$ of the supreme level. At the summative stage of the experiment, we looked at the dependence (according to the Yerkes - Dodson Law) of the development of the students' required level of FLC in the experimental group on their motivation for using elements of psychological support at the foreign language lessons. With this purpose, we varied the difficulty of professionally oriented exercises in the control and experimental groups.

The results analysis has shown that each student has his/her standard range of motivation at which the achievements in FLC development in the experiment group is at its maximum level, compared to that in the control group. The range of students' motivation also influences the level of complexity of exercises that the experimental group did at the foreign language lessons (fig. 2).

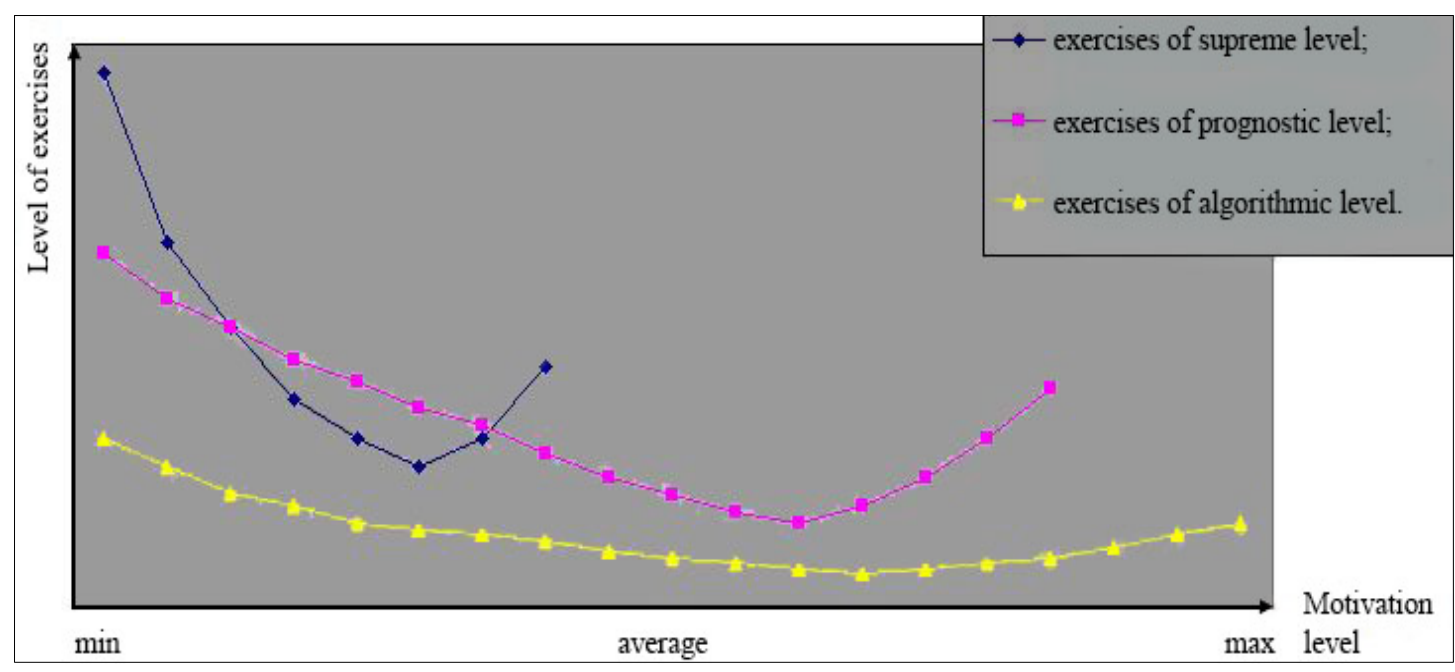

Figure 1. General dynamics of the cutoff knowledge coefficient (CRC) distribution (input/output testing) a) input testing b) output testing 

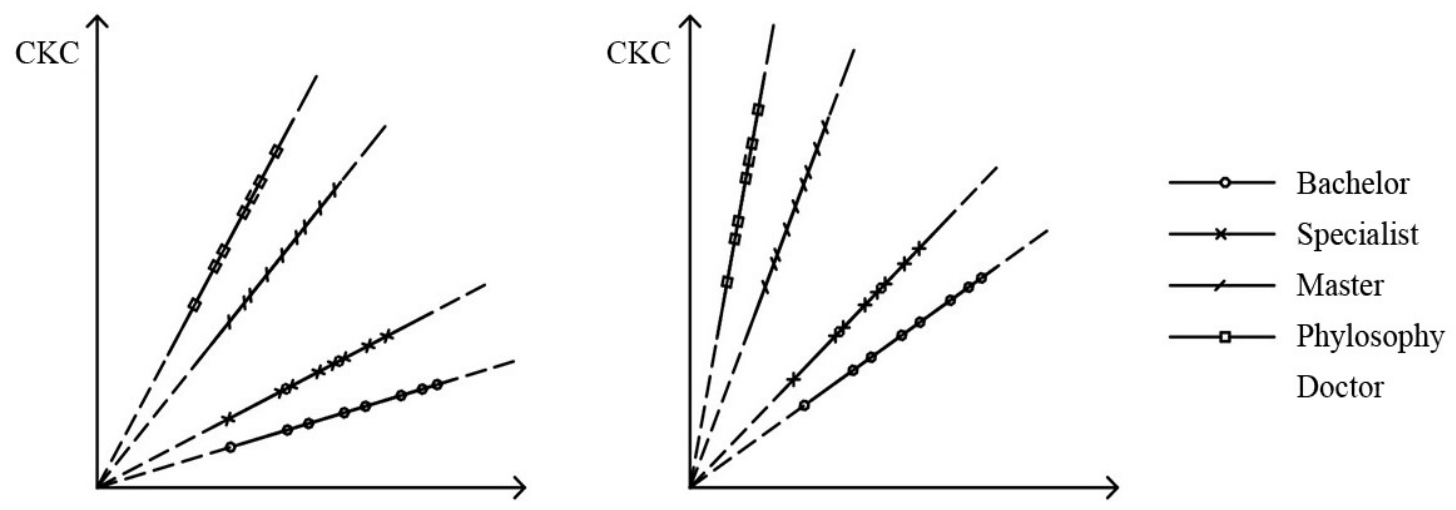

Figure 2. Influence of the motivation level on the exercises complexity

Table 2. Dynamics of the development of students' foreign language skills and stress- management abilities

\begin{tabular}{|c|c|c|c|c|}
\hline \multirow{2}{*}{ FLC Level } & \multicolumn{3}{|c|}{ Testing } \\
\cline { 2 - 5 } & Control group & Experimental group & Control group & Experimental group \\
\cline { 2 - 5 } & 14.3 & 14.7 & 16.1 & 24.4 \\
\hline Supreme & 48.1 & 47.9 & 44.0 & 48.9 \\
\hline Prognostic & 37.6 & 7.4 & 39.9 & 26.7 \\
\hline Algorithmic & & & \multicolumn{3}{|c|}{ Input, \% } \\
\hline
\end{tabular}

As seen from figure 2, if the students from experiment group are able to do exercises of supreme level then they have the minimum motivation level. In order to be able to do algorithmic level of exercises, the students' motivation should be at its maximum. In the control group, the maximum level of motivation lowered the learning performance that could be accounted for high emotional tension and anxiety causing decline of their foreign language activity.

Students' use of stress-management techniques in the experimental group, unlike in the control group, helped to cope with these negative consequences and contributed to the increase of the supreme level of FLC by $9.8 \%$ (fig. 2). Also, the teachers, having knowledge of the majority of students' motivations involving them in the active use of stress-management techniques at the foreign language lessons, could deliberately influence the development of their FLC supreme level in the most effective way. This contributed to the increase of quality, but not quantity exponents of the students learning achievements in the experimental group by $11 \%$. The dynamics of the development of students' foreign language skills and stress-management abilities is shown in table 2 .

Summative research results show the decrease in performance of students with algorithmic level of FLC in experiment group by $11.7 \%$, and the decrease of supreme level by $9.8 \%$ and $5.9 \%$ with prognostic level in comparison to the results in the control group. It testifies the rationale and effectiveness of an integrative use of FLC and stress management techniques at the foreign language training of the students in the area of international relations.
We introduced general, innovational and special stress-management techniques at the foreign language lessons. General stress-management techniques were used to activate students' memory, attention and reaction, speed up their nerve system processes, decrease tension, remove tremor, anxiety, uncertainty as well as to increase self-discipline, which is key to the development of the supreme level of professional FLC.

The innovational techniques include using music in stress-management exercises such as "Musical and psychological massage", "Musical and philosophic autotraining", "Musical meditation". The aim of these exercises is to develop students' cognitive sphere and ability for stress-management through listening to the music compositions (concerts) by W. Mozart, G. Handel, I. Bach, F. Chopin, F. Mendelssohn. In these exercises music plays a secondary role and, ideally, each of these exercises should be an organic combination of thoughts and feelings. The exercises are done when students reach the autogenic state.

By using these exercises, students execute further cognitive and emotional development. These exercises also helped to reveal and better understand different aspects of their attitudes towards educational and professional situations. Exercising these techniques allows the would-be professionals' in international relations to more easily switch between foreign language and professional activity. It also activates the capacities of the human in case of overexhaustion (late lessons) and contributes to singling out the key issues from the abundance of information, helps nervous stability and emotional isolation from everything 
that is not essential, stimulates attention and vigilance. These exercises are of particular help at the stage prior to the commencement of foreign language lessons, which requires great concentration and cognitive efforts.

Special stress- management techniques, unlike the ones described above, were used for the development of the supreme level of professional FLC in all four skills: speaking, reading, listening, and writing. We found it useful to practice speaking skills by using the following exercises:

"Active muscle relaxation" and a similar one, called "Isometric gymnastics", aimed at decreasing unintentional muscles tension that contributed to the removal of anxiety and nervous tension, increasing concentration and vigilance;

"Passive muscle relaxation" exercise is very useful for the would-be professionals' in international relations concentration on sensor signals coming from certain muscle groups and their further relaxation whilst concentrating.

In practicing foreign language speaking skills, we used "Active muscle relaxation" techniques with the aim of relaxing muscles not involved in these actions as well as for the control over the group of muscles, mostly strained while exercising or performing functions in the foreign language environment. Because small motor skills are closely connected with the speaking organs, some instant stress-management exercises helped to decrease psychological tension, and strengthen concentration in speaking.

All these contribute to acquiring skills in combating stresses, improving personal and professional communication, abilities to solve problems, keeping appropriate psychological climate within the study group that, in general, increases students' communicative skills.

In this way, the students' achievements can be improved through the purposeful development of the student's personality, his/her values and motivation for getting professional education in international relations area. These exercises and techniques can, on the one hand, help successful foreign language learning, and, on the other hand, to effectively get used to the professional activity in the foreign language environment.

In conclusion, the relaxation of some muscles help students to avoid disruption of speaking and reading. Besides, short texts do not cause excessive nervous tension. Therefore, the use of short time breathing and changing thinking exercises can be sufficient.

We selected exercises to practice listening skills according to the basic phases of work with text, such as pre-listening, while-listening, post-listening.

Here, students may turn out not to be psychologically ready to listen to the text in order to understand, withdraw and remember the information for its further use. Therefore, in order to prevent this, at the pre-listening phase the general exercises enabled students to achieve the state of tranquility that is the indication of their general readiness for listening. It affects anticipation skills and helps to prevent language difficulties. Besides, by practicing some general stress-management exercises students can get ready for context anticipation that, in its turn, contributes to the development of global audiotext understanding.

At the while-listening phase (listening to the audiotext and further practicing exercises), the students should remain at the state of adequate mobilization achieved by using special techniques, primarily based on "Active muscles relaxation" exercises. The post-listening phase practices lexical and grammar skills in listening comprehension, abilities of global, detailed and selective text understanding, as well as measuring compensation skills involving background knowledge, non-linguistic and non-verbal information in audiotexts.

All these skills require intensive speaking, intellectual activity, and short-term memory activation, combination of various foreign language actions that can cause anxiety, uncertainty and continuous emotional tension. Here, we offer students to go through a number of confidence-building exercises, to concentrate on breathing, to focus on the task, and on positive thinking using individual program of psychological support.

It facilitates interpersonal communication skills as well as the abilities to prevent conflicts, contributes to high level of empathy and as the result - a high level of emotional intelligence.

Writing as a component of FLC requires a number of other skills that causes excessive nervous tension, tremor and uncertainty in their level of professional competence. In order to overcome stress factors breathing exercises, functional music, confidence-building exercises, combined with active and passive muscles relaxation were recommended to students. Using these exercises students support optimum level of writing without excessive strain, despite any conditions.

\section{Conclusions}

The comparison analysis of performance by groups using and not using stress-management techniques in FLT shows that the level of FLC in the experiment group has increased by $20 \%$ more than that in the control group.

The use of stress management techniques and exercises is a key element of psychological support for the professional FLT in international relations educational institutions. It contributes to the development of specialists' high level of FLC. It also helps to intensify the process of understanding and acquiring integrative skills for the creational solution of foreign language situational problems as well as to the optimum level of motivation for foreign language learning.

The answers in the questionnaires offered to the respondents have shown students' positive attitude towards 
using stress-management techniques and exercises in professional FLT. While selecting stress-management techniques we looked at such criteria as efficiency, availability, and positive acceptation.

Here, the techniques and exercises based on them depend much on the type and form of speech the students practice at the FLT lessons. The most effective innovational techniques include functional music implemented in exercises such as "Musical and psychological massage", "Musical and philosophic autotraining", "Musical meditation". Special stressmanagement techniques, primarily used for practicing reading and speaking skills, include "Active muscles relaxation", which helps to prevent anxiety and nervous tension as well as to improve concentration through the decrease of spontaneous muscles tension. We also used "Passive muscles relaxation" exercises to help students' concentration. The selection of stress-management techniques in practicing listening skills depends on the phase of the listening process.

We also tried this type of FLT on two groups of students in international relations, which turned out to be effective. In general, the stress-management techniques and exercises being used in combination with practicing language skills have sufficient methodological and theoretical grounds and real practical implementation that contributes to the development of a high level of FLC - a prerequisite for the effective performance of professional functions.

\section{REFERENCES}

[1] Bloshchynskyi, I. H. (2017). Enhancement of cadets' practical training at the National Academy of the State Border Guard Service of Ukraine named after Bohdan Khmelnytskyi. Science and Education. Vol. 4. 5-10.

[2] Bloshchynskyi I. H. (2017) Usage of Anki specialised program application during future Border Guard officers' independent foreign language professional training for passing state examination. Information technologies and learning tools. Vol. 58. No 2. 49-58.

[3] Karpushyna M., Bloshchynskyi I., Nakonechna A., Skyba K. (2019) Creating Meaningful Foreign Language Environment by Means of Content-based Starters. Universal Journal of Educational Research 7.122710 2716. doi: 10.13189/ujer.2019.071219.

[4] Lahodynskyi, O. S. (2018) Inshomovna pidhotovka fakhivtsiv ekstremalnykh vydiv diyalnosti: psykholohichnyi vymir [Foreign language training of high risk operatives: psychological dimension]. Strategies of intercultural communication in the language training of modern higher educational institutions. Paper presented at the 4th International research and practice conference, Kiev National Economic University named after Vadym Hetman, Kiev, 15th March. (pp. 238-243). Kiev: KNEU [in Ukrainian]
[5] Lahodynskyi, O.S. \& Semeniako, I.M. (2018) Second language teaching strategies within the framework of individualisation and differentiation in higher educational institutions. Journal of Teaching English for Specific and Academic Purposes. Vol. 6. No. 1. 107-114. Retrieved August 16 2018, from of Teaching English for Specific and Academic Purposes website, DOI: 10.22190/JTESAP1801 $107 \mathrm{~L}$

[6] Leontyev, A. A. (2007) Yazyk, rech, rechevaya deyatelnost [Language, speech, speech activity]. Moscow: KomKniga. 216 p. [in Russian]

[7] Nayenko, N. I. (1976) Psikhicheskaya napryazhennost [Psychic tension]. Moscow: Nauka. 214 p. [in Russian]

[8] Nikolayeva, S.Yu. (2010) Tsili navchannia inozemnych mov $\mathrm{v}$ aspekti kompetentnisnoho pidhodu [Goals of foreign language learning in the aspect of competence approach]. Inozemni movy [Foreign Languages]. No. 2. 11-17. [in Ukrainian]

[9] Nosenko, E. L. (1981) Emotsionalnoye sostoyaniye i rech [Emotional state and speech]. Kiev: Vyshcha shkola. 195 p. [in Russian]

[10] Rybnikov, V.Yu. \& Ashanina, E.N. (2011) Psikhologiya koping-povedenija opasnykh profesiy [Psychology of stress management behavior of high risk operatives]. St. Petersburg: Politekhnika servis. 120 p. [in Russian]

[11] Smirnov, B. A. \& Dolgopolova E. V. (2007) Psikhologiya deyatelnosti $\mathrm{v}$ ekstremalnykh situatsiyakh [Psychology of high risk activity]. Kharkov: Gumanitarnyi tsentr. 276 p. [in Russian]

[12] Stasyuk, V. V. (2000) Ekstremalni umovy ta yikh vplyv na indyvidualni osoblyvosti viyskovosluzhbovtsiv [High risk environment and its influence on individual peculiarities of military personnel]. Zbirnyk naukovykh prats Viyskovoho humanitarnoho instytutu Natsionalnoi akademii oborony Ukrainy [Research works of the Military humanities institute of Ukrainian National Defense Academy]. No 6. 43-49. [in Ukrainian] 